\title{
A Study on the Optimization of a Spacecraft Structure by Using Coupled Load Analysis Model and Modal Transient Analysis
}

Do-Soon Hwang*, Young-Shin Lee** and In-Gul Kim***

\begin{abstract}
In this paper, an optimization algorithm is suggested to reduce the huge computation time in the optimum design of large structures, especially in spacecraft structures. It combines the coupled load analysis model using a constrained mode of component mode synthesis and the modal transient analysis. The computer simulation code is developed and evaluated in optimizing spacecraft platforms. The developed algorithm can alleviate the computational load with adequate accuracy. From the optimization of a spacecraft structural member, the characteristics of each structural member can be understood.
\end{abstract}

\section{초 록}

본 연구에서는 대형 구조물의 최적설계에서 문제되는 많은 계산시간과 컴퓨터의 계산능 력을 최소화할 수 있도록 부분구조합성법의 하나인 구속모드법을 이용한 연성하중해석 모 델 및 모달과도해석을 포함한 최적화 절차를 제시하였다. 제안된 방법의 수치모사를 위한 프로그램을 개발하여 위성체 주요 구조부재인 플랫폼에 대한 최적화를 수행함으로써 그 타당성을 검증하였다. 제안된 기법을 통해 초기설계 단계에서 정확성을 유지하면서 계산시 간을 단축할 수 있었고 위성체 구조부재에 대한 최적화를 수행하여 각각의 구조부재에 대 한 특성을 파악함으로써 설계 활용방안을 제시하였다.

Key Words : Coupled Load Analysis(CLA, 연성하중해석), Modal Transient Analysis(모 달과도해석), Spacecraft Structure(위성 구조체), Optimization(최적화), Launch Vehicle(발사체), Component Mode Synthesis(부분구조합성법), Modal Response(모달 응답)

\section{I. 서 론}

인공위성에서 위성 구조체의 임무는 위성체의

† 2003년 7월 25일 접수 2003년 12월 29일 심사완료

* 정회원, 한국항공우주연구원

연락저자, E-mail : dshwang@kari.re.kr

대전시 유성구 어은동 45 번지

** 정회원, 충남대학교 기계설계공학과

*** 정회원, 충남대학교 항공우주공학과
모든 부품을 제반 환경조건하에서 안전하게 지지 하는 것이다. 위성체는 접혀진 상태로 발사체의 탑재영역 내에서 조립되어 발사된다. 통상적으로 위성체의 형상설계가 이루어지면 보다 상세한 구 조체의 설계를 위하여 발사체에서 공급하는 규격 에 의한 준정적하중을 사용하여 구조해석을 수행 한다. 그러나 이 경우 유한요소 모델의 한계 및 발사하중의 변화요인 때문에 이를 검증할 필요성 이 발생한다. 이러한 이유로 인하여 준정적하중 
을 이용하여 설계된 위성체 구조부재의 건전성을 판단하기 위한 방안으로 발사체 제작자에 의한 연성하중해석(Coupled Load Analysis, CLA)을 수행한다. 연성하중해석은 위성체 모델과 발사체 모델을 결합하여 발사시 유기되는 발사하중을 전 체 연성모델에 부가함으로써 위성체에 작용하는 하중을 구하는 방법으로 위성체 개발자는 연성하 중해석 결과를 평가하여 위성체 구조부재가 안전 한 지를 평가하게 된다[1,2].

이 경우 발사체의 특성에 따라 위성체 구조부 재의 재설계 필요성이 제기되는 경우가 종종 발 생한다. 재설계된 위성체의 모델은 발사체 제작 자에게 다시 전달되어 별도의 연성하중해석을 수 행하여야 하는데 여기에 소요되는 시간이 3 6개 월로 매우 길고 추가의 비용이 필요하게 된다[3]. 또한 위성체 개발에 따른 제작일정도 지연되기 때문에 전체 일정이 지연되어 필요한 시기에 위 성체의 임무를 달성할 수 없게 되는 등 여러 가 지로 경제적 손실이 발생한다. 이러한 이유 때문 에 위성체 제작자는 중량을 고려하지 않고 구조 부재를 매우 강건하게 설계하는 것이 일반화 되 어있는 실정이다. 그러나 위성체의 발사비용은 $\mathrm{kg}$ 당 0.5 억원 내외이며 중량에 의존한다. 즉, 강 건한 위성 구조체 설계에 따른 추가 발사비용을 감수할 경우가 대부분이다.

이러한 비효율적인 부분을 개선할 방법의 하나 는 최적화 기법을 사용하는 것이다. 그러나 대형 구조물의 최적화는 많은 계산시간과 컴퓨터의 계 산능력을 필요로 하므로 이러한 문제점에 대한 해결방법이 요구되어 왔다. 따라서 본 연구에서 는 초기 구조설계 단계에서 정확성을 유지하면서 계산시간을 단축할 수 있는 연성하중해석 모델 및 동적 발사하중을 이용한 모달과도해석이 포함 된 통합 최적화 알고리듬을 제시한다.

부분구조합성법의 하나인 연성하중해석은 위성 체와 발사체가 결합된 상태의 구조부재 응답을 분석하는데 있어 매우 정확한 예측을 가능하게 해준다[4,5]. 부분구조합성법에 대한 최근의 많은 연구[6-9]가 수행되고 있으며 Ghosh 등[10]은 부 분구조의 경계와 모달 자유도에 관해 표현될 필 요가 있는 내부하중을 표현하기 위해 상용 소프 트웨어인 MSC/NASTRAN을 사용하여 부분구조 합성법을 정식화하였고 Paul 등[11,12]은 국제 우 주정거장에 탑재하기 위해 우주왕복선을 이용하 여 발사되는 소형 압력용기와 지지구조물에 대하 여 연성하중해석을 수행한 바 있다. 이와 같은 실제 연구와 더불어 위성체 구조가 변경되었을 경우에 연성하중해석 대신 재해석을 수행하기 위
한 연구[13-15]가 수행된 바 있다.

발사환경 하에서 위성체에 작용하는 하중을 분 석하기 위한 방법으로 발사체와 위성체가 결합된 연성모델에 대한 연성하중해석 이외에 위성체 모 델만을 사용하여 위성체 구조부재의 응답을 추출 하는 과도응답 해석을 수행하는 방법[16]이. 있다. 동적 진동은 많은 항공우주 시스템에 있어서 매 우 중요한 설계 요소이다. 즉, 실제적으로 생각해 볼 때 거대 우주 구조물은 경량이면서 매우 유연 하게 설계된다. Kodiyalam 등[17-20]은 위성체에 사용되는 구조부재에 대한 최적설계를 수행한바 있으며 Vidal 등[21]은 지난 30여년 동안 대형 문제의 특성 때문에 실제 응용이 아닌 연구용으 로만 수행되어져 왔던 민감도 문제를 상용 소프 트웨어의 도입으로 해결하고자 하였다.

그러나 이상에서의 연구동향에서 살펴본 바와 같이 위성체의 최적화는 연성하중해석 모델을 사 용하지 않고 전체 위성체 모델을 대상으로 수행 되고 있기 때문에 많은 계산시간을 필요로 한다. 또한 위성체에 작용하는 하중을 얻기 위한 방법 으로 부분구조모델인 연성하중해석 모델에 직접 적으로 동적 발사하중을 적용하지 않고 있으므로 결과의 신뢰성이 감소될 우려가 있다.

본 연구의 목적은 연성하중해석 방법을 도입하 여 동적 발사하중을 받는 대형 구조물의 초기 구 조설계에서 설계의 신속성과 신뢰성을 높일 수 있는 최적화 알고리듬을 통합 개발하는 것이다.

동적 발사하중의 부가를 위하여 사용한 모달과 도해석은 시간 추이에 따라 위성체 구조부재에 작용하는 하중을 추출하는 것으로 장기간 소요되 는 연성하중해석에 비해 매우 짧은 시간에 하중 응답을 구할 수 있다. 이때 위성체 모델은 실제 모델을 사용하지 않고 하중 응답 특성을 신속히 얻을 수 있는 연성하중해석 모델을 사용한다. 또 한 작용하중으로는 준정적하중이 아닌 동적 발사 하중을 사용하여 보다 신뢰성 있는 결과를 얻고 자 한다.

\section{II. 해석기법}

부분구조합성법은 구조물을 몇 개의 부구조물 로 나누고 각각의 부구조물을 동적 모델링한 후 부구조물의 동적 특성과 고유 모드, 그리고 부구 조물 간의 연결조건을 적용하여 부구조물을 새로 이 변환된 자유도로 합성하여 원하는 진동 모드 까지의 동적 특성과 외력을 받는 부구조물과 연 결된 다른 부구조물의 동적 거동을 해석하는 것 
이다. 본 연구에서는 운동방정식의 자유도를 감 소시키기 위하여 결합부를 모드좌표로 표현하여 정식화하는 방법인 Craig-Bampton 방법을 사용 한다.

선형 동적 시스템의 운동방정식에서 $\{x\}$ 를 전체 자유도라고 하면 운동방정식을 다음과 같이 표현할 수 있다[4-6].

$$
[M]\{\ddot{x}\}+[C]\{\dot{x}\}+[K]\{x\}=\{f(t)\}
$$

여기서 $[M],[C]$ 와 $[K]$ 는 질량, 감쇠, 그리 고 강성행렬이다. 여기서 전체 자유도 $\{x\}$ 를 내 부자유도(interior DOF), $\left\{x_{l}\right\}$ 와 경계 자유도 (boundary DOF), $\left\{x_{B}\right\}$ 로 나누어 다음과 같이 표현할 수 있다.

$$
\{x\}=\left\{\begin{array}{l}
x_{I} \\
x_{B}
\end{array}\right\}
$$

또한 식 (2)를 식 (1)에 적용하고 식 (1)을 내부자 유도와 경계자유도로 표시하면 식 (3)과 같다.

$$
\begin{array}{r}
{\left[\begin{array}{cc}
M_{I I} & M_{I B} \\
M_{B I} & M_{B B}
\end{array}\right]\left\{\begin{array}{c}
\ddot{x}_{I} \\
\ddot{x}_{B}
\end{array}\right\}+\left[\begin{array}{cc}
C_{I I} & C_{I B} \\
C_{B I} & C_{B B}
\end{array}\right]\left\{\begin{array}{c}
\dot{x_{I}} \\
\dot{x_{B}}
\end{array}\right\}} \\
+\left[\begin{array}{cc}
K_{I I} & K_{I B} \\
K_{B I} & K_{B B}
\end{array}\right]\left\{\begin{array}{l}
x_{I} \\
x_{B}
\end{array}\right\}=\left\{\begin{array}{l}
f_{I}(t) \\
f_{B}(t)
\end{array}\right\}
\end{array}
$$

비감쇠 시스템인 경우에 식 (3)은 다음과 같이 된다.

$$
\begin{array}{r}
{\left[\begin{array}{ll}
M_{I I} & M_{I B} \\
M_{B I} & M_{B B}
\end{array}\right]\left\{\begin{array}{c}
\ddot{x}_{I} \\
\ddot{x_{B}}
\end{array}\right\}+\left[\begin{array}{ll}
K_{I I} & K_{I B} \\
K_{B I} & K_{B B}
\end{array}\right]\left\{\begin{array}{c}
x_{I} \\
x_{B}
\end{array}\right\}} \\
=\left\{\begin{array}{c}
f_{I}(t) \\
f_{B}(t)
\end{array}\right\}
\end{array}
$$

식 (4)의 윗부분(upper portion)을 고유치 문제에 대해 풀고 물리적 자유도 응답, $\left\{x_{I}\right\}$ 는 모달 응 답(modal response), $\left\{q_{N}\right\}$ 을 사용하여 식 (5)와 같이 표현할 수 있다.

$$
\left\{x_{I}^{N}\right\}=\left[\Phi_{N}\right]\left\{q_{N}\right\}
$$

여기서 $\left[\Phi_{N}\right]$ 은 구조물의 자유진동으로 정의되 는 구속형 정규화 행렬(fixed- interface normal mode matrix) 또는 내부구조물의 고유진동 모드 행렬이다. 이와 유사하게 구속형 모드는 구조물 의 어느 한 경계 자유도에서는 정적으로 단위 변
형을 가하고 다른 경계 자유도는 구속할 경우 생 기는 내부 자유도의 변형 응답으로 정의된다. 즉, 식 (4)로부터 내부자유도와 경계자유도는

$$
\left[\begin{array}{ll}
K_{I I} & K_{I B} \\
K_{B I} & K_{B B}
\end{array}\right]\left\{\begin{array}{c}
x_{I} \\
x_{B}=I_{B}
\end{array}\right\}=\left\{\begin{array}{c}
0 \\
R
\end{array}\right\}
$$

으로 표시되고 내부 자유도의 응답, $\left\{x_{I}\right\}$ 는 다 음의 식 (7)과 같이 경계자유도, $\left\{x_{B}\right\}$ 를 사용하 여 표현할 수 있다. 여기서 $\{R\}$ 은 경계지점에 서의 작용력을 나타낸다.

$$
\left\{x \begin{array}{c}
C \\
I
\end{array}\right\}=\left[\Phi_{C M}\right]\left\{x_{B}\right\}
$$

여기에서, 구속형 모드 행렬, $\left[\Phi_{C M}\right]$ 은

$$
\left[\Phi_{C M}\right]=-\left[K_{I I}\right]^{-1}\left[K_{I B}\right]
$$

\section{으로 나타낼 수 있다.}

내부자유도, $\left\{x_{I}\right\}$ 는 모달응답, $\left\{q_{N}\right\}$ 과 경계 자유도, $\left\{x_{B}\right\}$ 로 나타낼 수 있으므로 식 (5)와 식 (7)을 조합하여 Craig-Bampton 모달 모델에 관련 된 물리적인 유한요소에 대한 변환행렬, [ $\Phi_{d h}$ ] 를 구성할 수 있다. 전체 자유도는 내부 고유진 동 모드와 구속형 모드로 구성되며 새로운 변수 를 사용하여 표현할 수 있다.

$$
\{x\}=\left\{\begin{array}{c}
x_{I} \\
x_{B}
\end{array}\right\}=\left[\begin{array}{cc}
\Phi_{N} & \Phi_{C M} \\
0 & I_{B B}
\end{array}\right]\left\{\begin{array}{c}
q_{N} \\
x_{B}
\end{array}\right\}=\left[\Phi_{d h}\right]\left\{\begin{array}{c}
a_{N} \\
x_{B}
\end{array}\right\}
$$

여기서 변환행렬, $\left[\Phi_{d h}\right]$ 는

$$
\left[\Phi_{d h}\right]=\left[\begin{array}{cc}
\Phi_{N} & \Phi_{C M} \\
0 & I_{B B}
\end{array}\right]
$$

이다.

식 (9a)를 식 (4)에 대입하고 양변에 $\left[\Phi_{d h}\right]^{T}$ 를 곱하게 되면 동적 시스템은 Craig-Bampton 모델 형태로 되는데 이를 정리하면 다음과 같다.

$$
\begin{aligned}
& {\left[\begin{array}{cc}
G M_{I I} & G M_{I B} \\
G M_{B I} & G M_{B B}
\end{array}\right]\left\{\begin{array}{c}
\ddot{q_{N}} \\
\ddot{x_{B}}
\end{array}\right\}+\left[\begin{array}{cc}
G K_{I I} & 0 \\
0 & G K_{B B}
\end{array}\right]\left\{\begin{array}{c}
q_{N} \\
x_{B}
\end{array}\right\} } \\
&=\left\{\begin{array}{c}
\Phi_{N}^{T} f_{I} \\
\Phi_{N}^{T} f_{I+} f_{B}
\end{array}\right\}
\end{aligned}
$$


여기서, $G M_{I I}, G M_{I B}, G M_{B B}, G K_{I I}$ 및 $G K_{B B}$ 는 일반화(generlized)된 질량 및 강성행렬로 각각의 항은 다음 식과 같이 표현된다.

$$
\begin{aligned}
G M_{I I}= & \Phi_{N}^{T} M_{I I} \Phi_{N} \\
G M_{I B}= & \left\{G_{B I}\right\}^{T}=\Phi_{N}^{T} \quad M_{I I} \Phi_{C M} \\
& +\Phi_{N}^{T} M_{I B} \\
G M_{B B}= & \Phi_{C M}^{T} M_{I I} \Phi_{C M}+M_{B I} \Phi_{C M} \\
& +\Phi_{C M}^{T} M_{I B}+M_{B B} \\
G K_{I I}= & \Phi_{N}^{T} K_{I I} \Phi_{N} \\
G K_{B B}= & K_{B I} \Phi_{C M}+K_{B B}
\end{aligned}
$$

따라서 일반화 질량행렬은 일반좌표계와 구속형 모드를 이용한 Craig-Bampton 형태의 변환좌표 계 사이에서 연성되고 일반화 강성행렬은 비연성 됨을 알 수 있다.

식 (10)의 윗부분으로부터

$$
\begin{aligned}
{\left[G M_{I I}\right]\left\{\ddot{q}_{N}\right\}+\left[G M_{I B}\right]\left\{\ddot{x}_{B}\right\} } \\
+\left[G K_{I I}\right]\left\{q_{N}\right\}=\left\{\Phi_{N}^{T} f_{I}\right\}
\end{aligned}
$$

을 얻어낼 수 있다.

구조물의 내부 각 점에서 작용하는 외력은 0 이 다. 즉, $\left\{f_{l}\right\}=0$ 이다. 그러면 식 (13)은 다음과 같이 된다.

$$
\left[G M_{I I}\right]\left\{\ddot{q}_{N}\right\}+\left[G K_{I I}\right]\left\{q_{N}\right\}=-\left[G M_{I B}\right]\left\{\ddot{x}_{B}\right\}
$$

여기서 $\left[G M_{I B}\right]$ 를 모드형 관계요소라 하는데, 식 (15)에서 보여지는 바와 같이 모드형 관계요소 의 정방행렬중 대각요소를 모드 영향질량(modal effective mass), $\left\{M_{\text {eff }}\right\}$ 이라 한다.

$$
\left\{M_{\text {eff }}\right\}=\left\{\operatorname{Diag}\left(\left[G M_{I B}\right]^{T}\left[G M_{I B}\right]\right)\right\}
$$

그리고 $\left\{\ddot{x_{B}}\right\}$ 는 발사체와 위성체의 경계조건에 서 작용하는 가속도 하중이며 식 (14)를 이용하여 다음과 같이 모달과도해석을 수행한다.

모달응답 $\left\{q_{N}\right\}$ 을 모달 좌표계 $\{\xi\}$ 로 변환하 여 다시 나타내면 다음과 같이 된다.

$$
q_{N}(t)=[\Phi]\{\xi(t)\}
$$

여기서 모드 형상 [ $\Phi$ ] 는 모드들의 거동에 관해 표현되도록 변환한다. 식 (16)에서 모든 모드들을 모두 사용할 경우에는 구조적 특성과 동일하게 표현되겠지만 그렇지 않고 일부 모드만을 사용할
경우에는 근사화되어 표현된다.

식 (16)을 이용하여 식 (14)를 비연성시키기 위 하여 양변에 $[\Phi]^{T}$ 를 곱하면 다음과 같이 된다.

$$
[\Phi]^{T}\left[G M_{I I}\right][\Phi]\{" \xi(t)\}+[\Phi]^{T}\left[G K_{I I}\right][\Phi]\{\xi(t)\}
$$

$$
=-[\Phi]^{T}\left[G M_{I B}\right]\left\{\ddot{x_{B}}\right\}
$$

여기서 , $[\Phi]^{T}\left[G M_{I I}\right][\Phi]$ : 모달 질량 행렬

$[\Phi]^{T}\left[G K_{I I}\right][\Phi]$ : 모달 강성 행렬

$[\Phi]^{T}\left[G M_{I B}\right]$ : 모달 하중 벡터

이다.

정방행렬인 모달 질량 및 강성 행렬에 관해 운 동방정식을 정식화하기 위해 모드 형상의 직교성 을 이용한다. 이 행렬들은 비대각항의 값을 갖지 않으므로 운동방정식은 연성되지 않는다. 이렇게 연성되지 않은 형태를 이용하여 1자유도계의 집 합으로 구성된 시스템에 대하여 운동방정식을 다 음과 같이 쓸 수 있다.

$$
m_{i} \ddot{\xi}_{i}(t)+k_{i} \xi_{i}(t)=f_{i}(t)
$$

여기서, $m_{i}: \mathrm{i}$ 번째 모달 질량

$$
\begin{aligned}
& k_{i}: \mathrm{i} \text { 번째 모달 강성 } \\
& f_{i}: \mathrm{i} \text { 번째 모달 하중 }
\end{aligned}
$$

이다.

각각의 모달 응답 $\xi_{i}(t)$ 가 계산되면 물리적 응답은 식 (16)과 같은 모달 응답의 합으로 표현 할 수 있다.

또한 구조부재에 작용하는 하중 또는 구조물의 응답은 출력변환행렬, [OTMX] 와 물리적인 변 위 응답으로부터 얻어진다.

$$
\begin{aligned}
\{L\} & =\left[\text { OTMX] }\left\{\begin{array}{c}
x_{I} \\
x_{B}
\end{array}\right\}\right. \\
& =\left[\text { OTMX] }\left[\begin{array}{cc}
\Phi_{N} & \Phi_{C M} \\
0 & I_{B B}
\end{array}\right]\left\{\begin{array}{c}
q_{N} \\
x_{B}
\end{array}\right\}\right. \\
& =\left[\text { OTMCB] }\left\{\begin{array}{l}
q_{N} \\
x_{B}
\end{array}\right\}\right.
\end{aligned}
$$

여기서 $\{L\}$ 은 출력 벡터이고, [OTMCB] 는 Craig-Bampton 모달 응답으로부터의 가속도 변환행 렬, [ATM], 변위 변환행렬, [DTM] 및 하중 변환행 렬, [LTM] 의 정보가 포함된 행렬이다.

아래 식은 [ATM], [DTM] 및 [LTM] 으로 
표현된 응답특성을 보여주고 있다.

$$
\begin{aligned}
\{\ddot{x}\} & =\left\{\begin{array}{c}
\ddot{x}_{I} \\
\ddot{x_{B}}
\end{array}\right\}=\left[\begin{array}{cc}
\Phi_{N} & \Phi_{C M} \\
0 & I_{B B}
\end{array}\right]\left\{\begin{array}{c}
\ddot{q}_{N} \\
\ddot{x_{B}}
\end{array}\right\} \\
& =[A T M]\left\{\begin{array}{c}
\ddot{q_{N}} \\
\ddot{x}_{B}
\end{array}\right\} \\
\{x\} & =\left\{\begin{array}{c}
x_{I} \\
x_{B}
\end{array}\right\}=\left[\begin{array}{cc}
\Phi_{N} & \Phi_{C M} \\
0 & I_{B B}
\end{array}\right]\left\{\begin{array}{c}
q_{N} \\
x_{B}
\end{array}\right\} \\
& =[D T M]\left\{\begin{array}{c}
q_{N} \\
x_{B}
\end{array}\right\} \\
\{\text { Load }\} & =[F L T M]\{f\}+[D L T M]\left\{x_{B}\right\}
\end{aligned}
$$

식 (22)에서 $\{L o a d\}$ 는 하중이나 부재에 걸리는 하중 벡터, [FLTM] 은 힘으로 표현된 하중 변 환행렬, $[D L T M]$ 은 변위 하중 변환행렬, $\{f\}$ 는 주어진 시간에서의 내부자유도에 작용하는 힘 벡터를 나타낸다. 여기서 $\{f\}$ 를 질량과 가속도 로 바꾸어 표현하면 하중 벡터는 다음과 같다.

$$
\begin{aligned}
\{L o a d\}= & -[F L T M][M]\left\{\ddot{x}_{B}\right\} \\
& +[D L T M]\left\{x_{B}\right\}
\end{aligned}
$$

가속도 하중 변환행렬, [ALTM] 은 다음과 같 이 정의할 수 있다.

$$
[A L T M]=-[F L T M][M]
$$

또한 하중벡터를 가속도 하중 변환행렬과 변위 하중 변환행렬을 이용하여 표현하면 다음과 같 다.

$$
\begin{aligned}
& \{\text { Load }\}=[A L T M]\left[\begin{array}{cc}
\Phi_{N} & \Phi_{C M} \\
0 & I_{B B}
\end{array}\right]\left\{\begin{array}{c}
\ddot{q_{N}} \\
\ddot{x_{B}}
\end{array}\right\} \\
& +[D L T M]\left\{x_{B}\right\} \\
& {[A L T M]=-[F L T M][M]}
\end{aligned}
$$

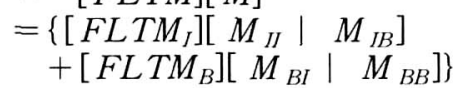

식 (26)에서 [FLTMI] 는 비접속 자유도에서 힘 으로 표현된 하중 변환행렬이고, $\left[F L T M_{B}\right]$ 는 접속 자유도에서 하중 변환행렬이다.

힘에 의한 하중 변환행렬의 요소 $[F L T M]_{i j}$ 는 접속부의 자유도를 고정시키고 $j$ 지점에 단위 하중을 가할 때 내부자유도 $i$ 지점에서의 내력값
으로 정의된다. 변위에 의한 하중 변환행렬의 요 소, $[D L T M]_{i j}$ 는 접속부의 $j$ 번째 자유도에만 단위 변위를 가하고 접속부의 다른 자유도를 고 정시켰을 때 내부자유도 $i$ 지점에서의 내력값으 로 정의된다.

이때 각 분계의 접속부 구조형상이 정정구조물 (statically determinate structure)일 경우에는 [DLTM] 은 0이 되고 식 (25)에서 부재 내력을 구할 때 고려하지 않아도 된다.

아울러 본 연구에서는 범용으로 사용되는 최적 설계 프로그램인 ADS Ver. 2.01을 사용하였으며 최적화를 수행하기 위하여 비선형 문제를 선형화 하여 푸는 순차선형계획법을 사용한다. 또한 최 적화 알고리듬으로는 유용방향법을 사용하며 탐 색을 위한 방법으로는 다항식 근사를 사용한다.

\section{III. 발사 하중조건}

본 연구에서는 하중함수로서 시간 추이에 따른 가속도를 사용한다. 시간 추이에 따른 하중함수 는 발사체가 위성체를 탑재하고 발사될 때 실제 로 측정되어진 하중에 불확실한 요인들을 추가한 불확실성 계수(uncertainty factor)와 적정 크기의 안전여유(safety factor)를 더하여 사용한다.

본 연구에서 사용한 발사체는 발사를 포함한 비행기간 중에 발사, 버펫, 천음속 돌풍, 초음속 돌풍 및 공진 연소와 같은 5 가지의 기본적인 하 중단계를 거쳐서 궤도에 진입한다.

하중함수는 가속도 응답점에 의해 정의된 연성 하중해석 모델을 사용한 모달과도해석을 수행할 때 입력 하중으로 사용한다. 모달과도해석은 시 간추이에 따라 구조부재에 작용하는 하중을 구하 는 방법이다. 입력에 사용되는 하중함수의 형태 는 0.01초 간격의 하중값으로 도표화되어 있으며 이 자료를 사용하게 된다. 각각의 발사단계는 3 축 및 세 개의 회전방향 등 6가지의 하중함수로 표현되며 Fig. 1은 x축 방향의 하중함수의 예를 나타낸다.

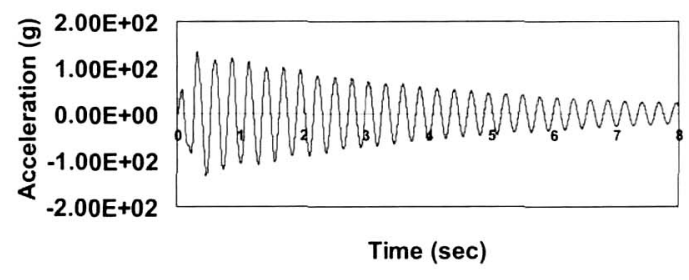

Fig. 1. Forcing function example 


\section{IV. 수치적 검증}

위성체 구조부재의 최적화를 수행하도록 개발 된 알고리듬을 검증하기 위하여 3-bar 트러스 모 델 및 위성체 주요 구조부재인 플랫폼 모델에 대 하여 수치적 검증을 수행하였다.

본 연구에서 개발한 유한요소모델, 연성하중해 석 모델, 모달과도해석 및 최적화 과정이 통합된 일련의 알고리듬을 3-bar 트러스 예제에 적용하 여 수치적 검증을 수행하였으며 플랫폼 모델에 대하여는 전체모델과 연성하중해석 모델을 사용 하는 두가지 경우에 있어서 해석시간의 단축여부 에 대한 검증을 수행하였다.

\subsection{3-bar 트러스 모델}

3-bar 트러스 모델은 참고문헌 [22]에 나타나 있는 것으로서 본 연구에서 개발된 알고리듬을 적용하여 정확도를 비교하고 고찰함으로써 프로 그램 내에서 해석자료의 교환, 최적화 수행 등과 같은 전체 과정이 올바르게 수행되는 지를 확인 하였다. 즉, 구조해석 프로그램과 최적화 프로그 램의 연결 알고리듬에 대한 검증이 수행되었다.

비대칭 3-bar 트러스의 모델은 Fig. 2와 같다. 본 모델은 3 개 부재의 단면적들을 설계변수로 사 용하여 중량을 최소화시키는 것이 목적이다. 설 계변수는 트러스 구조 각각의 단면적이다. 제약 조건은 재질 특성에 따른 허용 강도와 트러스 구 조 각각에 대한 최소 단면적이다.

본 연구를 통하여 개발된 알고리듬을 적용하여

Table 1. Comparison of optimized results between this study and Morris[22]

\begin{tabular}{|c|c|c|c|}
\hline Description & Morris[22] & This study & Deviation \\
\hline DV1 & $14.23 \mathrm{in}^{2}$ & $14.31 \mathrm{in}^{2}$ & $0.56 \%$ \\
\hline DV2 & $4.926 \mathrm{in}^{2}$ & $4.919 \mathrm{in}^{2}$ & $0.14 \%$ \\
\hline DV3 & $0.100 \mathrm{in}^{2}$ & $0.109 \mathrm{in}^{2}$ & $9.00 \%$ \\
\hline
\end{tabular}

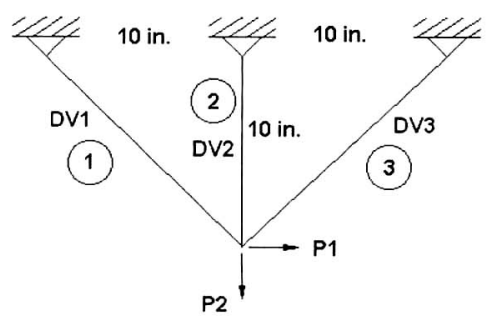

Fig. 2. 3-bar truss configuration to verify the optimization program as test problem
수행된 결과와 참고문헌 [22]의 결과를 비교하면 Table 1과 같다. 비교에 따르면 본 연구의 결과 와 참고문헌에서 제시한 결과가 매우 잘 일치하 고 있음을 알 수 있다.

\section{2 플랫폼 모델}

수치적 검증을 위하여 선정한 구조부재는 위성 체의 부품이 장착되는 플랫폼으로서 이 구조부재 는 적절한 강성과 강도를 지녀야 한다. 이때 최 적화를 위하여 선정한 플랫폼의 형상은 Fig. 3 과 같으며 이에 대한 유한요소모델은 Fig. 4 와 같다. 여기서 Fig. 3은 투시도로 나타낸 플랫폼의 실제 형상이다. 또한 Fig. 4의 유한요소모델은 하니콤 샌드위치 구조를 셀요소, 플랫폼 모서리의 레일 을 바요소, 플랫폼 상부에 부착되는 부품들을 집 중질량요소를 사용하여 모델링하였다.

플랫폼은 강성 요구조건인 고유진동수와 하니 콤 패널의 파손모드에 대한 요구조건인 가속도 응답을 제약조건으로 최적화가 수행된다[23].

설계 최적화 문제는 하니콤 샌드위치 구조의 파손모드에 대해 + 값의 안전여유 요구조건을 갖 도록 가속도 응답조건을 제약하는 조건에서 무게 를 최소화하도록 수행한다. 설계변수는 하니콤 샌드위치 구조의 면재 두께, 심재 두께 및 패널

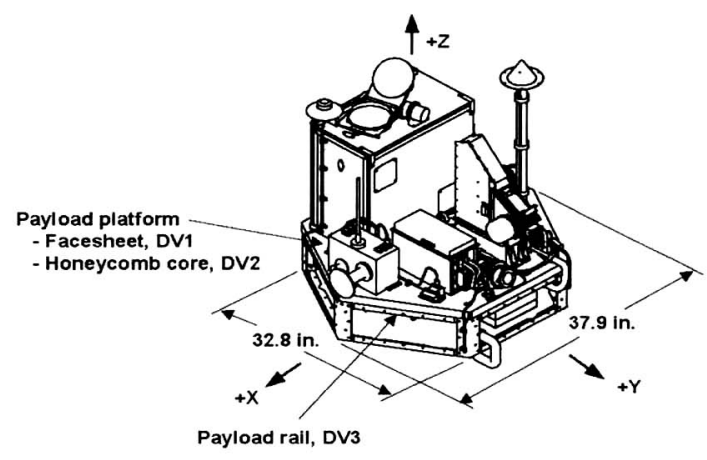

Fig. 3. Description of design variables of platform model

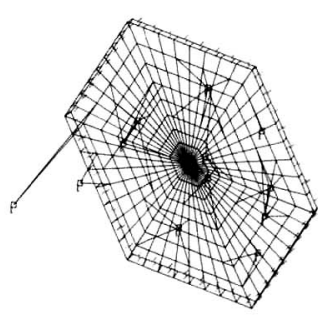

Fig. 4. Spacecraft platform model to optimize the spacecraft structure member 
모서리를 지지하는 레일의 단면적이다.

\section{3 검증 결과}

본 연구에서 제시한 연성하중해석 모델 및 동 적 발사하중을 이용한 모달과도해석을 포함한 최 적화 알고리듬을 적용하는 방법과 연성하중해석 모델을 사용하지 않고 전체모델 및 모달과도해석 을 이용하여 최적화를 수행하는 방법을 비교, 분 석하였다.

이 두 가지 방법의 비교를 위해 현재 한국항공 우주연구원에 설치되어 있는 Hewlett Packard사 의 HP715 workstation에서 최적설계가 독립적으 로 수행되었다. HP715는 $100 \mathrm{MHz}$ 의 클럭 속도 를 가지며 48.7 Mflops의 연산속도를 갖는다. 이 때 사용된 소프트웨어는 항공우주분야의 상용 구 조해석 프로그램인 MSC/NASTRAN 68.2[24]와 최적설계 프로그램인 ADS 2.01[25]이다. ADS 프 로그램은 Fortran 언어로 작성되어 있으며 $\mathrm{MSC} / \mathrm{NASTRAN}$ 과 ADS 프로그램의 접속 및 데 이터 교환 등을 위하여 별도로 개발된 C 프로그 램을 사용한다.

Table 2는 본 연구에서 개발한 방법과 전체모 델을 이용하여 최적설계를 수행한 결과에 대해 나타내고 있다. 전체모델을 사용할 경우와 비교 하여 볼 때 본 연구에서 개발한 방법에 대한 최 적설계 결과에 따르면 목적함수는 $21.5 \%$ 증가하 는 반면에 총소요시간은 $90.9 \%, \mathrm{CPU}$ 시간은 $67.2 \%$ 감소하여 매우 짧은 시간에 결과를 얻을 수 있었다.

이것은 본 연구에서 제시한 방법이 연성하중해 석 모델을 별도로 구성한 뒤 질량행렬과 강성행 렬만을 이용하여 모달과도해석을 수행하는데 반 해 전체 모델에 대한 모달과도해석을 수행하는

Table 2. Comparison of optimized result and elapsed time between this study and full model

\begin{tabular}{|c|c|c|c|c|}
\hline Description & $\begin{array}{c}\text { Full } \\
\text { model }\end{array}$ & $\begin{array}{c}\text { This } \\
\text { study }\end{array}$ & Difference & $\begin{array}{c}\text { Reduction } \\
\text { ratio }\end{array}$ \\
\hline $\begin{array}{c}\text { Optimized } \\
\text { object } \\
\text { function } \\
\text { (lbs) }\end{array}$ & 14.76 & 17.93 & 3.17 & $-21.5 \%$ \\
\hline $\begin{array}{c}\text { Iteration } \\
\text { number }\end{array}$ & 91 & 30 & 61 & $67.0 \%$ \\
\hline $\begin{array}{c}\text { Run time } \\
\text { (sec) }\end{array}$ & 113,820 & 10,348 & 103,472 & $90.9 \%$ \\
\hline $\begin{array}{c}\text { CPU time } \\
\text { (sec) }\end{array}$ & $1,749.0$ & 574.4 & $1,174.6$ & $67.2 \%$ \\
\hline
\end{tabular}

경우에는 플랫폼 전체 모델에 대한 자유도를 모 두 이용하기 때문에 훨씬 많은 시간이 소요됨을 알 수 있다. 그러나 전체 모델을 이용하는 경우 에는 플랫폼이 가지고 있는 자유도에 대한 효과 를 모두 고려하기 때문에 보다 정확한 최적설계 결과를 얻을 수 있는 장점이 있다.

따라서 위성체 구조부재와 같은 대형 구조물의 최적화를 위해 본 연구에서 제시한 방법을 사용 하면 초기설계 단계에서 어느 정도 정확성을 유 지하면서 계산시간을 충분히 단축할 수 있을 것 으로 판단된다.

\section{V. 위성체 모델}

\section{1 위성체 유한요소모델}

본 연구에서는 일반적인 위성의 특성을 대부분 보유하고 있는 다목적실용위성을 사용하여 위성 체 모델 해석을 수행한다[26]. Fig. 5는 다목적실 용위성의 형상을 보인다. 위성체는 발사체를 사 용하여 발사되며 발사과정 중에는 태양전지판이 접혀진 상태가 된다. Fig. 6은 위성체 주요 구재 부재를 나타내고 있다. 플랫폼, 패널 및 태양전지 판은 알루미늄 면재 및 하니콤 코어를 갖는 샌드

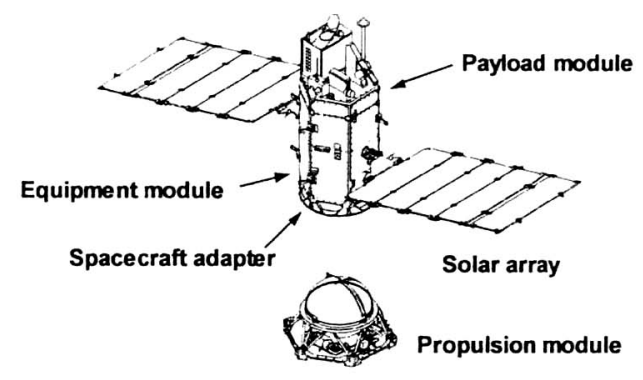

Fig. 5. Spacecraft configuration and module descriptions for optimization problem

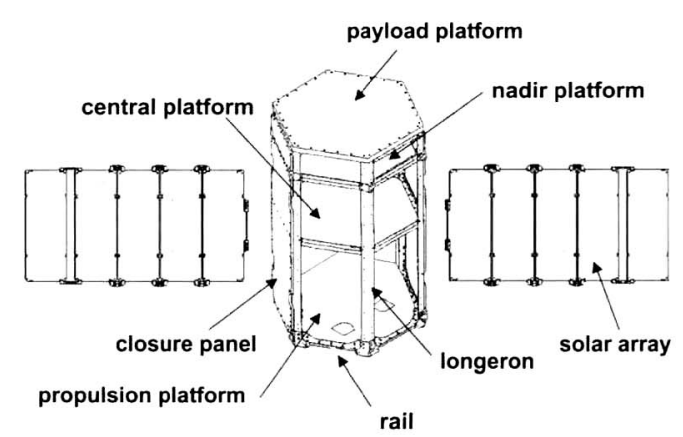

Fig. 6. Structural member of spacecraft 


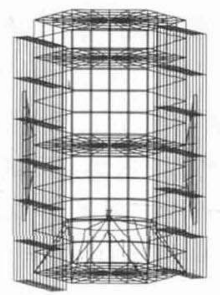

Fig. 7. Spacecraft model for optimization problem in relation to CLA

위치 구조, 론저론은 알루미늅 압출재, 레일은 알 루미늄재의 가공품이다.

Fig. 7은 위성체의 유한요소모델을 나타낸다. 작성된 유한요소모델의 검증을 위하여 강체 여부 확인, 중량 확인 및 고유진동수와 모드형상 확인 을 수행한다. 특히 강체 여부 확인은 위성체의 유한요소모델을 이용한 해석에서 유효한 결과가 나올 수 있도록 하기 위해 결함을 갖지 않은 모 델인지를 검증하는 것이 목적으로 강체 모드의 존재여부를 확인함으로써 이루어진다.

\section{2 연성하중해석 모델}

본 연구에서는 위성체 구조부재에 대하여 최적 화를 수행하기 위한 연성하중해석 모델을 다음과 같이 구성하였다. 연성하중해석 모델은 유한요소 모델로부터 생성된다. 우선 내부자유도 및 경계 자유도를 결정한다. 결정된 자유도를 바탕으로 하여 모달응답을 구한 후 위성체 동적 시스템을 Craig-Bampton 형태로 변환한다.

Craig-Bampton 형태로 변환된 동적 시스템에 대하여 응답특성을 분석하기 위하여 출력변환 행 렬을 작성한다. 이때 작성된 출력변환행렬의 응 답은 최적화 과정에서 제약조건으로 도입된다.

본 연구에서는 내부자유도를 $150 \mathrm{~Hz}$ 이하의 모든 고유진동수에 대하여 고려하였다. $150 \mathrm{~Hz}$ 이상의 고차모드에서는 동적반응 효과가 적으므 로 일반적으로 무시한다. 경계자유도는 위성체와 발사체의 접속지점에 대하여 한 지점을 결정하여 사용하였다.

출력 변환 행렬은 총 40 개 지점으로 각 플랫폼 의 모서리 및 중심부, 추진제 탱크의 집중질량부, 요크 및 태양전지판의 모서리와 중심부를 선정하 였다. 선정된 응답점은 총 123 개의 행으로 작성 되었으며 $150 \mathrm{~Hz}$ 이하의 자유도와 위성체와 발 사체 접속점의 6 개 자유도의 합이 열로 작성되었다.

\section{3 구조체 최적화 모델}

위성체 구조는 매우 복잡하고 여러 가지 종류
의 부재로 연결되어 있으며 경험에 의한 부재 크 기결정은 구조체를 필요 이상으로 매우 강건하게 설계할 수 있다.

최적화 설계변수는 하중경로 상에서 중량을 줄 일 수 있는 구조부재에 대하여 선정한다. 즉, 실 제 하드웨어에 대한 제작성을 고려하여야 하며 구조적으로 안전하여야 한다.

위성체 구조부재의 최적설계에서 가장 중요한 설계제약조건은 위성체가 발사시 가져야하는 최 소 횡방향 고유진동수를 우선적으로 만족하도록 하는 것이다.

또한 위성체 구조부재의 최적설계 과정을 통해 구조부재의 안전성을 평가할 수 있도록 준정적하 중을 제약조건으로 설정하였다. 본 연구에서 제 시되고 있는 최적설계는 동적 발사하중자료를 외 부 하중으로 사용하여 수행된다. 위성체 모델 및 연성하중해석 모델이 작성되면 모달 과도해석을 통해 발사 하중자료를 부가함으로써 시간 추이에 따른 가속도 응답을 얻을 수 있다.

위성체 구조부재의 최적설계 과정을 통하여 최 소화시키고자 하는 목적함수는 위성체 전체 중량 이 아니라 설계변수로 선정된 구조부재의 중량을 최소화하도록 정의하였다.

위성체 모델에 대한 목적함수 및 제약조건은 다음과 같은 식으로 나타낼 수 있다.

\section{Minimize :}

$$
\begin{aligned}
F= & \left(t_{f s, p a} \cdot A_{p a}+t_{f s, n} \cdot A_{n}\right. \\
& +t_{f s, c} \cdot A_{c}+t_{f s, p r} \cdot A_{p r} \\
& \left.+t_{f s, c p} \cdot A_{c p}+t_{s, s a} \cdot A_{s a}\right) \cdot \rho_{f s} \\
& +\left(t_{c, p a} \cdot A_{p a} \cdot \rho_{p a}+t_{c, n} \cdot A_{n} \cdot \rho_{n}\right. \\
& +t_{c, c} \cdot A_{c} \cdot \rho_{c}+t_{c, p r} \cdot A_{p r} \cdot \rho_{p r} \\
& \left.+t_{c, c p} \cdot A_{c p} \cdot \rho_{c p}+t_{c, s a} \cdot A_{s a} \cdot \rho_{s a}\right) \\
& +\left(A_{r, p a} \cdot l_{p a}+A_{r, n} \cdot l_{n}\right. \\
& \left.+A_{r, c} \cdot l_{c}+A_{r, b r} \cdot l_{p r}\right) \cdot \rho_{r} \\
& +A_{\text {long }} \cdot l_{\text {long }} \cdot \rho_{\text {long }}
\end{aligned}
$$

Subject to :

$$
\begin{aligned}
& f_{s} \geq 20.0 \\
& a_{p a} \leq 13.5 \\
& a_{n} \leq 13.0 \\
& a_{c} \leq 12.0 \\
& a_{p r} \leq 12.0 \\
& a_{s a} \leq 14.0 \\
& 0.04 \leq t_{f s, p a} \leq 0.1 \\
& 0.04 \leq t_{f s, n} \leq 0.1 \\
& 0.04 \leq t_{f s, c} \leq 0.1
\end{aligned}
$$




$$
\begin{aligned}
& 0.04 \leq t_{f, p r} \leq 0.1 \\
& 0.02 \leq t_{f s, c p} \leq 0.1 \\
& 0.008 \leq t_{f s, s a} \leq 0.1 \\
& 0.8 \leq t_{c, p a} \leq 2.0 \\
& 0.5 \leq t_{c, n} \leq 2.0 \\
& 0.5 \leq t_{c, c} \leq 2.0 \\
& 0.4 \leq t_{c, p r} \leq 2.0 \\
& 0.4 \leq t_{c, c p} \leq 2.0 \\
& 0.4 \leq t_{c, s a} \leq 2.0 \\
& 0.2 \leq A_{r, p a} \leq 0.5 \\
& 0.2 \leq A_{r, n} \leq 0.5 \\
& 0.2 \leq A_{r, c} \leq 0.5 \\
& 0.2 \leq A_{r, p r} \leq 0.5 \\
& 0.5 \leq A_{\text {long }} \leq 1.0
\end{aligned}
$$

여기서,

$t_{f s, p a}, t_{f s, n}, t_{f s, c}, t_{f s, p r}, t_{f s, c p}, t_{f s, s a}$ : 탑재, 네이더, 중앙, 추진플랫폼, 측면패널 및 태양 전지판의 면재 두께

$A_{p a}, A_{n}, A_{c}, A_{p r}, A_{c p}, A_{s a}$ : 탑재,

네이더, 중앙, 추진플랫폼, 측면패널 및 태양 전지판의 표면적

$t_{c, p a}, t_{c, n}, t_{c, c}, t_{c, p r}, t_{c, c p}, t_{c, s a}$ : 탑재,

네이더, 중앙, 추진플랫폼, 측면패널 및 태양 전지판의 하니콤 심재 두께

$\rho_{f s}:$ 면재의 밀도

$\rho_{p a}, \rho_{n}, \rho_{c}, \rho_{p r}, \rho_{c p}, \rho_{s a}$ : 탑재, 네이더, 중앙, 추진플랫폼, 측면패널 및 태양전지판의 하니콤 심재 밀도

$A_{r, p a}, A_{r, n}, A_{r, c}, A_{r, p r}$ : 탑재, 네이더,

중앙, 추진레일의 단면적

$l_{r, p a}, l_{r, n}, l_{r, c}, l_{r, p r}$ : 탑재, 네이더, 중앙,

추진레일의 길이

$\rho_{r}$ : 레일의 밀도

$A_{\text {long }}$ : 론저론의 단면적

$l_{\text {long }}:$ 론저론의 길이

$\rho_{\text {long }}$ : 론저론의 밀도

$f_{s}$ : 위성체의 횡방향 고유진동수

$a_{p a}, a_{n}, a_{c}, a_{p r}, a_{s}$ : 탑재, 네이더, 중앙,

추진플랫폼 및 태양전지판에 작용하는 가속도 응답

\section{VI. 해석결과}

본 장에서는 연성하중해석을 이용하여 수행한 위성 구조체 최적화 결과를 제시한다. 특히 본 연구를 통하여 수행한 최적화 결과는 다목적실용 위성의 설계 및 해석결과와 비교되어 중량 감소 효과를 확인하고 각각의 구조부재에 대한 특성을 파악한다. 최적화 결과를 통하여 연성하중해석을 이용한 위성체 구조부재에 대한 최적화 알고리듬 적용에 대한 적합성 여부를 판단한다.

위성체 구조부재에 대하여 여러 가지 하중단계 중에서 $\mathrm{y}$ 축 방향의 바람의 영향을 받는 천음속 영역의 경우에 대하여 수행하였다.

또한 발사체에서 요구하는 위성체 설계 요구조 건인 고유진동수 요구조건의 최적설계 결과 및 추이를 고찰하여 구조부재의 공진영역을 확인하 고 어느 구조부재가 가장 큰 영향을 끼치는 지를 확인한다.

아울러 실제 위성체 구조부재의 설계변수로 사 용된 면재 두께, 하니콤 심재 두께, 레일 및 론저 론 단면적의 최적설계 추이를 고찰하여 최적화에 대한 영향 및 기여도를 확인하고 특성을 분석하 여 위성체 구조부재의 최적설계에 대한 활용방안 을 제시한다.

이러한 기본적인 고찰과 더불어 여러 가지 경 우의 동적 발사하중 단계에 따른 최적설계 결과, 유사한 조건과 능력을 갖는 여러 발사체의 고유 진동수 제약조건에 따른 최적설계 결과 등을 고 찰하고 확인한다.

\section{1 구조부재의 최적화 결과}

\subsection{1 구조 중량 특성}

본 연구를 통해 위성체 구조부재의 최적설계에

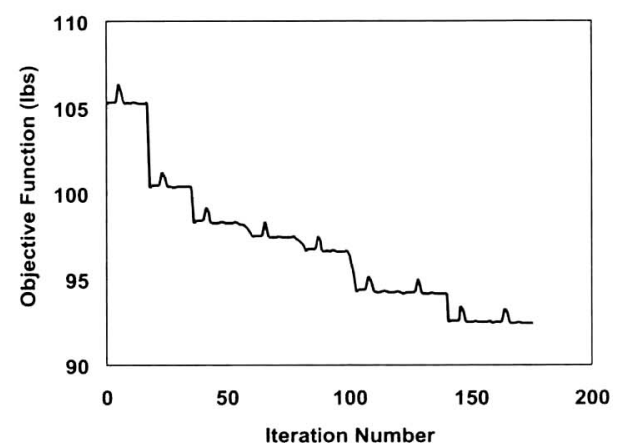

Fig. 8. History of objective function according to iteration number for spacecraft structure 
Table 3. Comparison of weight portion between initial and optimized design for spacecraft structure

\begin{tabular}{|c|c|c|c|c|c|}
\hline Case & Facesheet & $\begin{array}{c}\text { Honeycomb } \\
\text { Core }\end{array}$ & Rail & Longeron & Total \\
\hline \multirow{2}{*}{$\begin{array}{c}\text { Initial design } \\
\text { (Ibs) }\end{array}$} & 55.19 & 29.15 & 12.57 & 8.32 & 105.23 \\
\cline { 2 - 6 } & $52.5 \%$ & $27.7 \%$ & $11.9 \%$ & $7.9 \%$ & $100 \%$ \\
\hline $\begin{array}{c}\text { Optimized design } \\
\text { (lbs) }\end{array}$ & 52.72 & 23.20 & 10.17 & 6.37 & 92.46 \\
\cline { 2 - 6 } & $57.0 \%$ & $25.1 \%$ & $11.0 \%$ & $6.9 \%$ & $100 \%$ \\
\hline Difference (Ibs) & 2.47 & 5.95 & 2.40 & 1.95 & 12.77 \\
\hline Reduction ratio (\%) & 4.48 & 20.41 & 19.09 & 23.43 & 12.14 \\
\hline
\end{tabular}

Table 4. Design variables of spacecraft model for optimization of structural member

\begin{tabular}{|c|c|c|c|c|c|}
\hline Number & Design variables & $\begin{array}{l}\text { Initial } \\
\text { value }\end{array}$ & $\begin{array}{l}\text { Lower } \\
\text { bound }\end{array}$ & $\begin{array}{l}\text { Upper } \\
\text { bound }\end{array}$ & $\begin{array}{l}\text { Optimized } \\
\text { value }\end{array}$ \\
\hline DV1 & $\begin{array}{l}\text { Payload platform facesheet } \\
\text { thickness (in.) }\end{array}$ & 0.063 & 0.04 & 0.1 & 0.051 \\
\hline DV2 & $\begin{array}{c}\text { Nadir platform facesheet } \\
\text { thickness (in.) }\end{array}$ & 0.041 & 0.04 & 0.1 & 0.043 \\
\hline DV3 & $\begin{array}{c}\text { Central platform facesheet } \\
\text { thickness (in.) }\end{array}$ & 0.063 & 0.04 & 0.1 & 0.051 \\
\hline DV4 & $\begin{array}{c}\text { Propulsion platform facesheet } \\
\text { thickness (in.) }\end{array}$ & 0.05 & 0.04 & 0.1 & 0.051 \\
\hline DV5 & $\begin{array}{c}\text { Closure panel facesheet } \\
\text { thickness (in.) }\end{array}$ & 0.032 & 0.02 & 0.1 & 0.030 \\
\hline DV6 & $\begin{array}{c}\text { Solar array substrate facesheet } \\
\text { thickness (in.) }\end{array}$ & 0.01 & 0.008 & 0.1 & 0.011 \\
\hline DV7 & $\begin{array}{c}\text { Payload platform honeycomb core } \\
\text { thickness (in.) }\end{array}$ & 1.25 & 0.8 & 2.0 & 1.14 \\
\hline DV8 & $\begin{array}{l}\text { Nadir platform honeycomb } \\
\text { core thickness (in.) }\end{array}$ & 0.8 & 0.5 & 2.0 & 0.74 \\
\hline DV9 & $\begin{array}{l}\text { Central platform honeycomb core } \\
\text { thickness (in.) }\end{array}$ & 0.9 & 0.5 & 2.0 & 0.79 \\
\hline DV 10 & $\begin{array}{l}\text { Propulsion platform honey- } \\
\text { comb core thickness (in.) }\end{array}$ & 0.5 & 0.4 & 2.0 & 0.46 \\
\hline DV11 & $\begin{array}{l}\text { Closure panel honeycomb } \\
\text { core thickness (in.) }\end{array}$ & 0.5 & 0.4 & 2.0 & 0.41 \\
\hline DV 12 & $\begin{array}{l}\text { Solar array substrate honey- } \\
\text { comb core thickness (in.) }\end{array}$ & 0.6 & 0.4 & 2.0 & 0.40 \\
\hline DV 13 & Payload rail section area $\left(\right.$ in $\left.^{2}\right)$ & 0.2344 & 0.2 & 0.5 & 0.2132 \\
\hline DV14 & Nadir rail section area $\left(\mathrm{in}^{2}\right)$ & 0.2938 & 0.2 & 0.5 & 0.2008 \\
\hline DV15 & Central rail section area $\left(\mathrm{in}^{2}\right)$ & 0.2281 & 0.2 & 0.5 & 0.2072 \\
\hline DV16 & Propulsion rail section area $\left(\mathrm{in}^{2}\right)$ & $0.2594^{\circ}$ & 0.2 & 0.5 & 0.2007 \\
\hline DV 17 & Longeron section area $\left(\mathrm{in}^{2}\right)$ & 0.6716 & 0.5 & 1.0 & 0.5144 \\
\hline
\end{tabular}

대한 효용성을 보이기 위하여 최적설계의 초기 설계값으로 다목적실용위성의 설계값을 그대로 사용하였다. 이는 이미 설계되어 사용하고 있는 위성체에 대한 중량 감소 효과가 있는 지를 알아
보고자 함이다.

Fig. 8은 반복작업에 따른 목적함수의 변화 추 이를 보여준다. 그림에서 보는 바와 같이 최적설 계 대상으로 한 각각의 구조부재에 대한 총중량 
은 반복횟수에 따라 초기설계로부터 단계적으로 감소하고 있다. Table 3은 목적함수의 초기값과 최적화 결과를 나타낸다. Table 4 는 최적화 전후 의 설계변수에 대한 변화를 나타낸다.

최적화 결과에 따르면 위성체 구조부재의 중량 은 초기설계값인 $105.23 \mathrm{lbs}$ 에 대하여 최적설계 결과는 $92.46 \mathrm{lbs}$ 로 $12.14 \%$ 가 감소하여 원하는 중 량감소 효과를 충분히 얻을 수 있었다.

\subsection{2 고유진동수 특성}

위성체 구조부재의 최적설계를 통하여 가장 중 요한 제약조건이 바로 1차 횡방향 고유진동수이 다. 본 연구에서 사용한 위성체의 형상이 길이방 향으로 구성되어 있기 때문에 1 차 고유진동수는 횡방향의 모드가 발생한다. 바로 이 횡방향의 모 드가 제약조건이 되며 이 조건은 발사체와의 공 진을 방지하기 위한 기준이다.

Fig. 9는 최적화 전후의 고유진동수 모드형상 을 보여준다. 초기설계에서 $34.3 \mathrm{~Hz}$ 인 고유진동 수가 최적설계 결과 $23.8 \mathrm{~Hz}$ 로 $30.6 \%$ 감소하였으 며, 최적설계 종료시의 고유진동수 값은 발사체 와의 공진을 방지하기 위해 본 연구에서 설정한 최소 $20 \mathrm{~Hz}$ 의 요구조건에 대하여 충분한 여유를 갖는다.

\subsection{3 하니콤 샌드위치 구조부재}

하니콤 샌드위치 구조에서 면재는 인장 및 압 축하중, 내평면 전단하중과 같은 내평면하중 (in-plane load)을 감당한다. 면재는 위성체 구조 부재 중에서 가장 큰 중량을 갖는 부재이다. Table 3에서는 본 연구를 통하여 최적화하고자 하는 구조부재에 대한 초기설계 및 최적설계 결 과에서의 상대적인 점유비율을 보여준다.

면재는 초기설계에서 $55.19 \mathrm{lbs}$ 인 중량이 52.72 $\mathrm{lbs}$ 로 $4.48 \%$ 감소하였다. 그러나 위성체 구조부 재에서 면재의 점유비율은 초기설계 때보다 최적

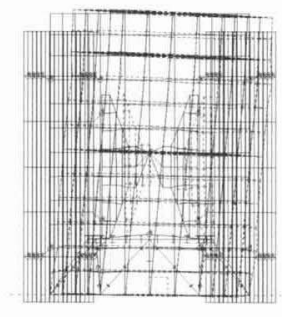

(a) Initial design $343 \mathrm{~Hz}$ )

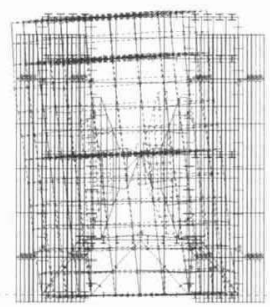

(b) Optimized design $(23.8 \mathrm{~Hz})$
Fig. 9. Mode shapes of initial and optimized design
설계 결과에서 현저히 증가한다. 초기값의 설정 이 어느 정도 정확히 예측되었다 하더라도 이 결 과에 따르면 면재의 두께는 발사하중과 연관된 최적설계에 크게 영향을 미치지 않고 있음을 알 수 있다.

하니콤 샌드위치 구조에서 면재가 내평면하중 을 담당하는 데 반해 하니콤 심재는 횡전단하중 (transverse shear loads)에 의해 발생하는 파손모 드를 주로 담당한다.

하니콤 심재는 초기설계에서 $29.15 \mathrm{lbs}$ 인 중량 이 최적화 이후에 $23.2 \mathrm{lbs}$ 로 $20.41 \%$ 감소하여 본 연구에서 설계변수로 고려하고 있는 다른 구조부 재에 비해 가장 큰 중량감소를 얻었다. 하니콤 심재는 위성체 구조부재에서 면재 다음으로 큰 중량 부분을 점유하고 있으며 최적설계 결과에서 나타나는 대부분의 중량 감소는 심재 두께의 감 소에서 나타남을 알 수 있다.

Fig. 11의 민감도해석 결과를 살펴보면 하니콤 샌드위치 구조에서 하니콤 심재는 면재보다 상대 적으로 최적화에 기여하는 영향이 큰 것을 알 수 있으며 하니콤 심재는 발사하중을 견디기 위한 강성 측면에서 설계가 수행될 필요가 있다.

\subsection{4 레일 및 론저론 구조부재}

위성 플랫폼의 하중을 가장 먼저 지지하게 되 는 레일은 축하중과 굽힘하중을 감당하고 론저론 으로 이러한 하중을 전달하는 역할을 수행하며 플랫폼에 장착된 위성체 부품들이 안전하게 유지 되는 역할을 수행한다.

Table 3에서 보는 바와 같이 레일은 초기설계 에서 $12.57 \mathrm{lbs}$ 인 중량이 최적화 이후에 $10.17 \mathrm{lbs}$ 로 $19.09 \%$ 감소한다.

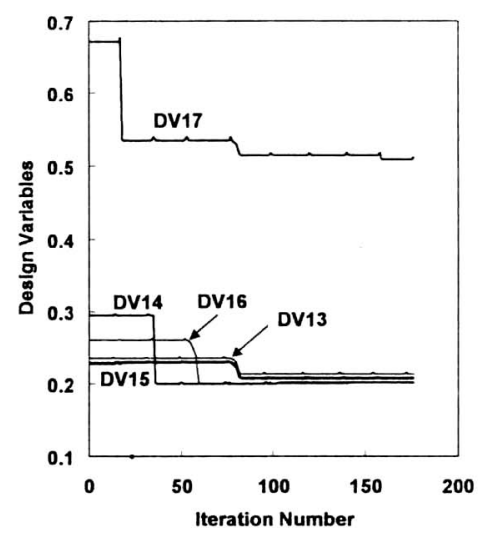

Fig. 10. History of design variables - rail area - according to iteration number for spacecraft structure 
Fig. 10은 반복작업에 따른 각 플랫폼의 레일 면적 변화 추이를 나타낸다. 각각의 레일에 대한 최적화 수행 결과는 초기설계 값으로부터 하한값 인 $0.2 \mathrm{in}^{2}$ 에 접근하고 있다. 이때 하한값은 레일 의 제작성을 고려한 최소 단면적이다. 이러한 결 과는 레일의 설계에 있어서 강도 및 제작성이 매 우 중요하며 이를 고려하여 설계가 수행되어야 함을 의미한다.

위성체 구조부재에 있어 주 지지구조인 론저론 은 레일로부터 전달받은 축하중과 전단하중을 감 당하고 이 하중을 위성체 어댑터로 전달하는 역 할을 수행한다.

Table 3에서 보는 바와 같이 론저론은 초기설 계에서 $8.32 \mathrm{lbs}$ 인 중량이 최적화 이후에 $6.37 \mathrm{lbs}$ 로 $23.43 \%$ 감소한다.

Fig. 10은 반복작업에 따른 론저론 구조의 면 적 변화 추이를 보여준다. 최적화 수행결과는 초 기설계 값으로부터 하한값인 $0.5 \mathrm{in}^{2}$ 으로 근접해 감을 보인다. 이때 하한값은 제작성을 고려한 최 소 단면적이다. 이는 레일의 경우와 마찬가지로 론저론의 설계에 있어서도 강도 및 제작성을 고 려하여 설계가 수행되어야 함을 의미한다.

\subsection{5 민감도 특성}

본 연구에서 설계변수로 고려하고 있는 하니콤 샌드위치 구조의 면재, 하니콤 심재, 레일 및 론 저론에 대한 최적설계 특성을 파악하기 위하여 민감도해석을 수행하였다. 민감도해석은 설계변 수로 설정된 위성체 구조부재의 특성을 알 수 있 게 해주며 최적설계 과정에서 어떠한 변수가 중 요한 역할을 하는지를 판단할 수 있게 한다.

Fig. 11은 목적함수에 대하여 각각의 설계변수 에 따른 민감도를 나타내고 있다. 여기서 나타난 민감도는 특정 설계변수의 변화량을 부피로 환산

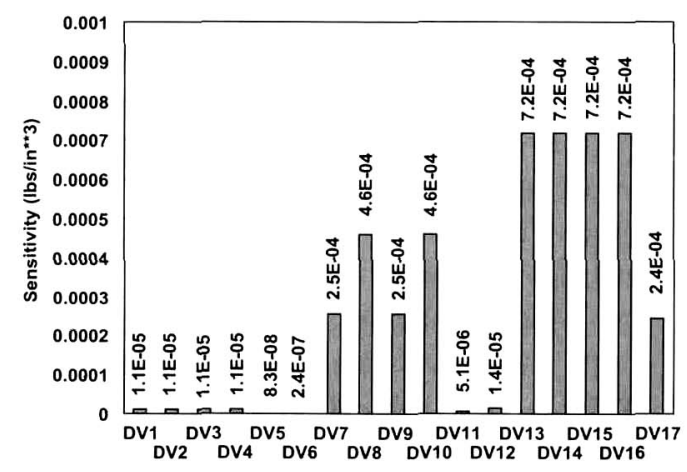

Fig. 11. Sensitivity characteristics for objective function to design variables for spacecraft structure
하여 이 값에 대한 목적함수의 변화량으로 표시 되었다. 즉 단위부피당 목적함수 변화량을 나타 내기 위하여 면재 및 하니콤 심재의 경우에는 설 계변수인 두께의 변화량과 표면적, 레일 및 론저 론의 경우에는 설계변수인 단면적의 변화량과 길 이로 나눈 값을 사용하였다. 또한 민감도 특성은 최적설계 초기 단계에서 수행되었으며 설계변수 의 변화량은 초기 설계값의 $1 \%$ 가 변화할 경우에 대하여 수행되었다. 그러나 초기 설계값의 $1 \%$ 변화량이 0.001" 미만인 면재의 경우에는 $0.001 "$ 의 값으로 수행하였다.

하니콤 샌드위치 구조에 있어 플랫폼 면재 (DV1 DV4)의 경우에 작은값을 나타내고 있으 며 태양전지판 면재(DV5) 및 측면패널 면재 (DV6)는 매우 작은 값을 나타낸다. 플랫폼 심재 (DV7 - DV10)와 태양전지판 심재(DV11) 및 측면 패널 심재(DV12)의 경우에는 면재보다 훨씬 큰 값의 민감도를 가지나 면재와 유사한 경향을 보 인다. 레일(DV13 DV16)의 경우는 매우 큰 값을 가지며 론저론(DV17)의 경우에도 일정한 값을 나타내고 있다. 따라서 민감도 특성을 살펴볼 때 레일, 하니콤 심재 및 론저론의 순서대로 목적함 수에 크게 영향을 끼치고 있는 것을 알 수 있으 며 면재의 경우에는 거의 영향이 없음을 알 수 있다. 면재의 경우에는 동일한 재질과 면적을 가 지고 있는 경우인 DV1 DV4의 경우 동일한 민 감도를 나타내며 하니콤 심재의 경우에도 DV7과 DV9, DV8과 DV10이 동일한 민감도를 나타낸다. 레일의 경우에는 모두 동일한 재질과 크기를 가 지고 있으며 동일한 민감도를 갖는다. 따라서 위 성체 구조부재의 최적설계에 있어 동일한 재질 및 크기 특성을 갖는 구조부재와 그렇지 않은 구 조부재의 최적설계 효과가 다름을 파악하여 설계 변수를 설정할 필요가 있다..

\section{2 발사조건에 따른 최적화 결과}

\subsection{1 하중단계에 따른 특성}

발사환경조건은 위성 구조체 설계에서 매우 중 요하게 고려되는 요소로 위성체를 궤도에 진입시 키기 위한 속도는 심각한 환경을 유발하게 되며 궁극적으로 위성체는 안전하게 정해진 고도와 궤 도에 도달하여 정상적인 임무를 수행할 수 있어 야 한다. 다목적실용위성을 발사하는 발사체는 발사 순간을 포함하여 시간대별로 상이한 환경변 화를 겪는다.

본 연구에서는 이러한 여러 단계 중에서도 특 히 심각한 하중단계인 발사, 공진연소 및 천음속 비행단계에 대하여 분석을 수행한다. 
Table 5. Various load cases of launch vehicle for optimization of spacecraft structure

\begin{tabular}{|c|c|c|c|}
\hline $\begin{array}{c}\text { Load } \\
\text { case }\end{array}$ & Description & $\begin{array}{c}\text { Iteration } \\
\text { number }\end{array}$ & $\begin{array}{c}\text { Objective } \\
\text { function } \\
\text { (lbs) }\end{array}$ \\
\hline loy & $\begin{array}{c}\text { Lift-off, } \\
\text { direction gust }\end{array}$ & 238 & 97.51 \\
\hline loz & $\begin{array}{c}\text { Lift-off, } \\
\text { z direction gust }\end{array}$ & 286 & 83.29 \\
\hline res_burn & $\begin{array}{c}\text { Motor resonant } \\
\text { burn }\end{array}$ & 237 & 83.78 \\
\hline gusty & $\begin{array}{c}\text { Transonic flight, } \\
\text { y direction gust }\end{array}$ & 176 & 92.46 \\
\hline gustz & $\begin{array}{c}\text { Transonic flight, } \\
\text { z direction gust }\end{array}$ & 157 & 94.25 \\
\hline
\end{tabular}

Table 5는 하중단계에 대한 반복횟수 및 목적 함수를 나타낸다. 최적화 결과, $\mathrm{y}$ 축 방향의 바람 의 영향을 받는 발사단계(loy)가 $97.51 \mathrm{lbs}$ 로 가장 무거운 중량을 가진다. 또한 이 경우에 각 구조 부재에 작용하는 가속도 응답이 가장 큼을 볼 때 이 단계의 하중이 위성체 구조부재에 가장 큰 영 향을 끼치고 있음을 나타내고 있는 것이다. 여러 가지 하중 단계 중에서 발사단계가 최악하중 조 건이며 이때 야기되는 순간적인 가속도 하중이 위성 구조부재에 전체적으로 영향을 끼치게 되어 구조설계에 가장 큰 영향을 미친다. 따라서 위성 체 구조설계를 수행할 때 동적 발사하중 측면에 서는 발사단계를 가장 우선적으로 고려하여야 한 다.

\subsection{2 발사체 종류에 따른 특성}

다목적실용위성과 같은 수백 $\mathrm{kg}$ 급의 위성을 발사하기 위하여 선정할 수 있는 발사체는 여러 가지가 있을 수 있다. 물론 각각의 발사체의 경 우에 있어서 부스터의 종류 및 사용 단수, 비행 조건 등에 따라 부가되어지는 하중의 크기는 변 화하게 된다. 이 경우 발사체의 종류에 따라 횡 방향 고유진동수 요구조건 또한 변화하게 된다. 그러나 발사체의 특성이 유사한 경우에 발사체 선정을 위한 기초자료로서 서로 다른 횡방향 고 유진동수 제약조건에 따라 최적설계 결과가 어떠 한 변화를 보이는지 고찰하는 것이 필요하다.

Table 6은 횡방향 고유진동수 요구조건에 따른 최적화 결과를 나타낸다. $18 \mathrm{~Hz}$ 이하의 요구조건 에서는 모두 동일한 결과를 나타내고 있음을 알 수 있다. 이는 본 연구를 위하여 부가한 하중조 건이 $22.7 \mathrm{~Hz}$ 이하의 고유진동수에서는 구조부재 들이 안전하지 않다는 것을 나타내는 것이다.
Table 6. The requirements of lateral frequency of various launch vehicle for KOMPSAT spacecraft

\begin{tabular}{|c|c|c|c|c|}
\hline $\begin{array}{c}\text { Selectable } \\
\text { launch } \\
\text { vehicle }\end{array}$ & $\begin{array}{l}\text { Min. } \\
\text { lateral } \\
\text { freq. } \\
\text { reqm't } \\
(\mathrm{Hz})\end{array}$ & $\begin{array}{l}\text { Iteration } \\
\text { number }\end{array}$ & $\begin{array}{l}\text { Objective } \\
\text { function } \\
\text { (Ibs) }\end{array}$ & $\begin{array}{c}\text { Final } \\
\text { frequency } \\
(\mathrm{Hz})\end{array}$ \\
\hline Cosmos & 10 & \multirow{4}{*}{286} & \multirow{4}{*}{83.29} & \multirow{4}{*}{22.73} \\
\hline LM-2C & 12 & & & \\
\hline Rockot & 15 & & & \\
\hline PSLV & 18 & & & \\
\hline Taurus & 25 & 188 & 96.11 & 25.20 \\
\hline
\end{tabular}

고유진동수 제약조건이 더 낮은 경우에 목적함 수의 감소가 현저함을 나타낸다.

따라서 발사체의 선정에 따른 위성 구조 부재 의 최적화는 횡방향 고유진동수 요구조건에 따라 변화하며 요구조건이 큰 경우 좀더 강건한 구조 부재의 사용이 필요하다는 것을 나타낸다. 위성 체 발사 요구조건을 만족하는 발사체가 여러 종 류 있을 경우, 횡방향 고유진동수 요구조건이 낮 고 유연한 구조로 설계된 발사체를 사용함으로써 더 가벼운 중량의 위성 구조체를 설계할 수 있 다. 또한 발사체의 설계 및 개발 측면에서도 발 사환경을 견디는 조건하에서 좀더 유연한 구조를 가지도록 하는 것이 필요하다.

\section{VII. 결 론}

연성하중해석 모델과 모달과도해석을 이용한 위성체 구조부재에 대한 최적화 연구를 통하여 다음과 같은 결론을 얻었다.

1) 플랫폼에 대한 수치적 검증을 통하여 본 연구 에서 제시한 연성하중해석 모델 및 동적 발사 하중을 이용한 모달과도해석을 포함한 최적화 알고리듬이 초기설계 단계에서 정확성을 유지 하면서 계산시간을 단축할 수 있는 방법임을 확인하였다.

2) 위성체가 발사체에 탑재되어 발사될 때 작용 하는 동적 발사하중을 위성체 연성하중해석 모델에 직접 부가함으로써 최적설계 결과의 신뢰성을 제고하였으며 위성체 구조부재의 재 설계로 인한 시간적, 경제적 손실을 방지할 수 있다.

3) 최적화 결과 실제 설계, 제작된 위성체 구조 부재에 비하여 $12.14 \%$ 의 중량 감소 효과를 
달성할 수 있음을 확인하였으며 최적화된 구 조부재의 칫수가 합리적임을 알 수 있었다.

4) 위성체 구조부재에 작용하는 여러 가지 하중 단계 중에서 발사의 경우가 가장 심각하였으 며 횡방향 고유진동수 요구조건이 작은 발사 체의 경우에 중량 감소 효과가 큼을 확인하였 다. 그리고 하니콤 심재가 동적 발사하중에 민감하며 레일 및 론저론은 하한값에 근접하 므로 강도와 제작성을 기준으로 설계가 수행 되어야 함을 확인함으로써 설계시 활용할 수 있는 구조부재의 특성 등을 제시하였다.

아울러 본 연구의 결과는 초기설계에서 구조부 재의 크기를 정확히 예측함으로써 설계에 소요되 는 기간을 단축하며 최적설계를 통한 위성체 구 조부재의 중량 감소는 발사비용을 줄이는데 기여 한다. 또한 본 연구의 결과는 우주분야 뿐만이 아니라 항공기 및 선박구조와 국제협력 혹은 여 러 기업에서 공동으로 개발하는 구조체의 부분구 조해석 및 구조 최적화에 적용할 수 있을 것으로 판단된다.

\section{참고문헌}

1) T. P. Sarafin, "Spacecraft Structures and Mechanisms" , Space Technology Library, 1995.

2) D. S. Hwang, "Design and Analysis of Satellite Structure" , KSAS Journal, Vol. 27, No. 2, 1999, pp. 111-121.

3) D. S. Hwang, "CLA Model and Assessment of Satellite" , KSAS Journal, Vol. 26, No. 7, 1998, pp. 108-115.

4) R. R. Craig, and M. C. Bampton, "Coupling of Substructures for Dynamic Analysis" , AIAA Journal, Vol. 6, No. 8, 1968, pp. 1313-1319.

5) W. A. Benfield, and R. F. Hruda, "Vibration Analysis of Structures by Component Mode Substitution" , AIAA Journal, Vol. 9, No. 7, 1971, pp. 1255-1261.

6) Y. T. Chung, "Dynamic Loads Recovery Using Alternative Mode Acceleration Approach" , AIAA Conference Proceedings, 1998, pp. 190-197.

7) J. A. Morgan, C. Pierre, and G. M. Hulbert, "Forced Response of Coupled Substructures Using Experimentally Based Component Mode Synthesis" , AIAA Journal,
Vol. 35, No. 2, 1997, pp. 334-339.

8) C. C. Flanigan, "Development of the its Component Dynamic Reduction Method for Substructure Analysis"

AIAA/ASME/ASCE/AHS/ ASC 32nd Structures, Structural Dynamics and Materials Conference. Part 4, 1991, pp. 2504-2514

9) K. F. Alvin, L. D. Peterson, and K. C. Park, "Minimal-Order Experimental Component Mode Synthesis: New Results and Challenges" , AIAA Journal, Vol. 33, No. 8, 1995, pp. 1477-1485

10) T. Ghosh, "Improved Method of Modal Synthesis in the Analysis of International Space-Station Structures" , AIAA/ASME/ASCE /AHS/ASC Structures, Structural Dynamics, and Materials Conference and Exhibit, 38th, and AIAA/ASME/AHS Adaptive Structures Forum, 1997 pp. 138-145.

11) P. S. Bookout, E. Ricks, and R. Jones, "Mini Pressurized Logistics Module(MPLM) /International Standard Payload Rack(ISPR) Coupled Loads Study" , AIAA Conference Proceedings, 1996, pp. 275-280.

12) R. Jones, E. Ricks, and P. S. Bookout, "Examination of Three Methods of Loads Recovery from a Coupled Loads Analysis on Space Shuttle Payloads" , AIAA Conference Proceedings, 1996, pp. 269-274.

13) Y. Yasui, "Improved Mode Superposition Reanalysis Method", Computers and Structures, Vol. 48, No. 4, 1993, pp. 711-717.

14) Y. Yasui, "Direct Coupled Load Verification of Modified Structural Components", AIAA Journal, Vol. 36, No. 1, 1998, pp. 94-101.

15) J. B. Ferris, M. M. Bernitsas and J. L. Stein, "Redesigning the Dynamics of Structural System" , AIAA Journal, Vol. 38, No. 1, 2000, pp. 147-154.

16) M. Vujcich, and C. Kuo, "Transient Load Analysis and Testing of QuikSCAT Spacecraft", The 41st AIAA/ASME/ASCE/AHS/ASC Structures, Structural Dynamics and Materials Conference, 2000, pp. 1-7.

17) S. Kodiyalam, and J. Molnar, "Sensitivity - Based Characterization and Optimization of Viscoelastically Damped 
Honeycomb Structures" , Journal of Guidance, Control, and Dynamics, Vol. 16, No. 3, 1993, pp. 484-489.

18) S. Kodiyalam, P. Kao, and G. Wang, "Analysis and Test Correlation of Spacecraft Structures Using Dynamic Parameter Sensitivities" , AIAA Journal, Vol. 32, No. 11, 1994, pp. 2286-2292.

19) S. Kodiyalam, C. Graichen, I. J. Connel, and P. M. Finnigan, "Object-Oriented, Optimization-Based Design of Satellite Structures" , Journal of Spacecraft and Rockets, Vol. 31, No 2, 1994, pp. 312-318.

20) S. Kodiyalam, S. Nagendra, and J. Destefano, "Composite Sandwich Structure Optimization with Application to Satellite Components" , AIAA Journal, Vol. 34, No. 3, 1996, pp. 614-621.

21) C. A. Vidal, K. Filho, W. K. Takahashi and P. N. DeSouza, "ENGINEERING NOTES -
Application of Sensitivity Analysis for Optimization of a Satellite Structure" , AIAA Journal, Vol. 37, No. 3, 2000, pp. 416-418.

22) A. J. Morris, Ed., "Foundations of Structural Optimization : A Unified Approach" , John Wiley \& Sons, 1982.

23) D. S. Hwang, Y. S. Lee and I. G. Kim, "Optimization Method of Structure by Using Coupled Load Analysis" , KSAS Journal, Vol. 30, No. 1, 2002, pp. 132-138.

24) M. Reymond and M. Miller, Ed., "MSC/ NASTRAN Quick Reference Guide" , The Macneal-Schwendler Corp., 1994.

25) G. N. Vanderplaats, "ADS - A Fortran Program for Automated Design Synthesis Version 1.10" , 1985.

26) D. S. Hwang, Y. S. Lee and I. G. Kim, "Optimization of Spacecraft Structure by Using Coupled Load Analysis", KSAS Journal, Vol. 30, No. 4, 2002, pp. 106-113. 